UDC 330.161

JEL classification: A10

Бігун У. В. (Bihun U.)

ORCID ID: 0000-0001-6013-2580

Національний технічний університет Украӥни

«Київський політехнічний інститут ім. Ігоря Сікорського»

National Technical University of Ukraine «Igor Sikorsky Kyiv Polytechnic Institute»

Шматенко Л. Г. (Shmatenko L.)

ORCID ID: 0000-0002-6132-1970

Дюссельдорфський університет імені Генріха Гейне

Heinrich-Heine-University of Düsseldorf

\title{
RECONCILIATION OF ECONOMIC INTERESTS OF ENTITIES ON THE ENERGY MARKET
}

\section{УЗГОДЖЕННЯ ЕКОНОМІЧНИХ ІНТЕРЕСІВ СУБ'ЄКТІВ ЕНЕРГЕТИЧНОГО РИНКУ}

\section{СОГЛАСОВАНИЕ ЭКОНОМИЧЕСКИХ ИНТЕРЕСОВ СУБЪЕКТОВ ЭНЕРГЕТИЧЕСКОГО РЫНКА}

Подано авторську інтерпретацію поняття «економічні інтереси». Виявлено залежність між діяльністю економічних агентів та їх економічними інтересами. Проаналізовано суб'єктно-функиіональну структуру економічних інтересів енергоринку. Виявлено горизонтальну та вертикальну взаємодію економічних інтересів учасників енергоринку. Визначено принципи горизонтальної взаємодї економічних інтересів суб'єктів енергетичного ринку. Розкрито протиріччя інтересів виробників $і$ споживачів електричної енергії. Відображено схему функціонування енергоринку на основі узгодження економічних інтересів його суб'єктів. Окреслено функиіонування енергетичного сектору у розрізі сфер держаного регулювання, співрегулювання та конкурентних механізмів. Розглянуто практику впровадження методу стимулюючого регулювання енергоринку на прикладі Німеччини. Виявлено прямі і непрямі ефекти впливу політики дерегулювання на функціонування енергетичного ринку. Запропоновано принщипи узгодження економічних інтересів учасників енергетичного ринку.

Ключові слова: економічні інтереси, суб'єкти енергетичного ринку, узгодження, енергоринок.

Представлена авторская интерпретация понятия «экономические интересы». Выявлена зависимость между деятельностью экономических агентов и их экономическими интересами. Проанализирована субъектно-функциональная структура экономических интересов энергорынка. Выявлено горизонтальное и вертикальное взаимодействие экономических интересов участников энергорынка. Определены принципы горизонтального взаимодействия экономических интересов субъектов энергетического рынка. Раскрыто противоречие интересов производителей и потребителей электрической энергии. Отражена схему функционирования энергорынка на основе согласования экономических интересов его субъектов. Определено функционирования энергетического 
сектора в разрезе сфер сфер государственного регулирования, совместного регулирования и конкурентных механизмов. Рассмотрена практика внедрения метода стимулирующего регулирования энергорынка на примере Германии. Выявлены прямые и косвенные эффекты влияния политики дерегуляции на функционирование энергетического рынка. Предложены принципы согласования экономических интересов участников энергетического рынка.

Ключевые слова: экономические интересы, субъекты энергетического рынка, согласование, энергорынок.

The authors' interpretation of the concept of «economic interests» is proposed. The dependence between the activities of economic entities and their economic interests is detected. The subject-functional structure of the economic interests in the energy markets is analyzed. Horizontal and vertical coordination of economic interests in the energy market as well as principles of horizontal interaction of economic interests in the energy market are detected. The contradiction of interests of producers and consumers of electricity is revealed. The scheme of the functioning of the energy market based upon the coordination of economic interests of its subjects is shown. Terms of state regulation, co-regulation and competitive mechanisms are outlines. The implementation practice of an incentive based energy regulation by the example of Germany is presented. Direct and indirect effects of deregulation policy and the functioning of the energy market as well as the principles of coordination of economic interests of the energy market are outlined. market.

Keywords: economic interests, entities on the energy market, harmonization, energy

Introduction. Economic globalization is one of the main preconditions of internalization which became the impulse in the process of the foundation of international energy markets, such as energy, oil and gas. In turn, crucial changes of world economy and its restructuring have a major impact on the system of the energy market players and their common interplay, which again leads to new economic interests and deeper analysis of the market. Thus, it is not the principle of a strict hierarchy «from the common to the individual» or vice versa which fulfills today's demands. It is the principle of harmonization of interests which is being tried to be achieved on different levels of socio-economic policy.

The problem of economic security in the light of economic policies following certain interests has been previously addressed by numerous scholars, such as Z. S. Varnalii [1], G. V. Kozachenko [2], V. I. Muntiian [3] and others. The issues of coordination of economic interests was addressed in scholar works of O. O. Alsufieva [4], V. L. Bezbozhnyi [5], N. V. Riabtseva [6]. The questions arising out of governmental competition policies, their influence on the behavior of the economic players have been analyzed in the scholar works of T. Duso [7], P. Joskov [8], A. Alesìni [9], A. Kalmenn [10].

Yet, the existing theoretical concepts of economic interests are not adapted to the requirements of a functioning energy market, making it necessary to analyze the question within the margins of the energy market. 
Setting objectives. The aim of the present research is to establish principles of the harmonization of the energy market players' interests to solve the controversies in the fields of production, transfer, sharing and using of electricity. According to the envisaged objective, the following tasks have to be accomplished: to analyze the economic interests of the entities that are active on the energy markets; to form a scheme of the functioning of a harmonized energy market; to precisely outline the mechanisms of energy market regulation.

Methodology. In the process of the research on the above mentioned problem, the following methods of research have been used: theoretical generalization, systematization and comparison - for the definition of the term «economic interests»; abstraction - for the establishment of groups of interest, that might be referred to certain players on the energy market; structural-functional approach - for the assignment of the character of a subjective-functional structure of the energy market; comparison - for the establishment of economic interests of participants acting on different levels of the energy market; analysis and synthesis for the research of scholar works dealing with the present topic.

Research results. Every state's energy market has a key role in the economy being crucial for the functioning of every single branch of industry being dependent on electricity. Schumacher E. F. pointed out that electricity cannot be replaced by comparable goods and even though it is purchased and sold like any other good, energy seized to be a blessing but turned into a necessity equal to air, water and plants [11, p. 107].

According to a temporary statement the borders of the energy market define a targeted management of the costs of the final product for the end-customer. Economic changes that are taking place in the energy market, are intervened with its reformation with the direct help from the market players. Yet again, efficient functioning of the energy market depends on the coordination of economic interests that arise in the production, transfer, sharing and usage.

The understanding of the term «interest» has philosophic, social, psychologic and economic aspects. This multidisciplinary makes it necessary to analyze the different approaches when trying to define the term. Particularly, in the Ukrainian law «On the basis of national security of Ukraine» [12] interests are defined as «vital material, intellectual and spiritual values ...».

Glina V. N. defines an economic interest as a necessity, which arises amongst groups or individuals of joint activities relative to factors of labor [13, p. 43]. Alsufieva O. O. [4] understands the «economic interest» as an objective manifestation of aggregated economic relations regarding the assumption of profits, which is recognized by the individual as concrete material goal.

Bearing in mind the authors' position in the need of delimitation the understandings of «necessity», «value» and «interest», the authors propose to define economic interests as a form of satisfaction of existing and developing needs based 
upon the principle of economic profit by means of material necessities of individuals, corporate entities and governments.

Economic interests are the main category to describe real reasons for a certain economic behavior of individuals. Being the main motif of action of economic agents, interests define their model behavior and their functional attitude towards production, distribution, exchange and usage of material goods.

Each system of economic relations has a counterpart in its own system of economic interests, as well as a structure of individuals being the carrier of economic interests. Figure 1 shows the subjective-functional structure of economic interests of the energy market. The groups on the energy market encompass regulation authorities, energy generating companies, distributive and supplying companies, end-customers and investors.

According to Figure 1 the vertical structure of economic interests represents a chain: general governmental economic interests - industrial economic interests industrial-organizational economic interests - industrial-individual economic interests - individual economic interests.

It shall be noted that the horizontal interplay of economic interests only takes place if results of the same level lead to a common profit, i.e. if there are intersectional of the results. E.g., the different competence of the Ministry of Energy and Coal as well as the Governmental Inspection of Nuclear Regulation of Ukraine (regulating authorities), follows the same aim being the functioning of energy supply and thus a common result - forming and realization of governmental policies in the energy fuel sector. In turn, horizontal interaction will be only streaking for those investors, which are united by a common project and endcustomers united by a common business or incorporation documents. 


\begin{tabular}{|c|c|c|}
\hline 节 & Type & Meaning \\
\hline 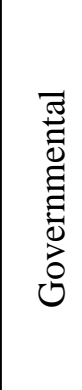 & Govermental & $\begin{array}{l}\text { Investment } \\
\text { attractiveness of the } \\
\text { sector; to balance } \\
\text { production and } \\
\text { consumption of } \\
\text { energy; prioritize } \\
\text { innovation. }\end{array}$ \\
\hline \multirow{3}{*}{ 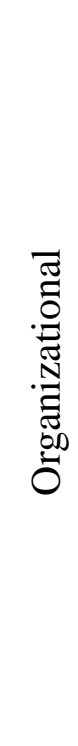 } & Industrial & $\begin{array}{l}\text { Profit maximization; } \\
\text { cost reduction; timely } \\
\text { payment for energy } \\
\text { produced }\end{array}$ \\
\hline & $\begin{array}{c}\text { Industrial- } \\
\text { organizational }\end{array}$ & $\begin{array}{l}\text { Accession of new } \\
\text { customers, increase } \\
\text { revenue by providing } \\
\text { energy and } \\
\text { maintenance services }\end{array}$ \\
\hline & $\begin{array}{l}\text { Industrial- } \\
\text { individual }\end{array}$ & $\begin{array}{l}\text { Reducing energy } \\
\text { costs; physical } \\
\text { adequacy and } \\
\text { reliability of power } \\
\text { supply }\end{array}$ \\
\hline : & Individual & $\begin{array}{l}\text { Increased profitability } \\
\text { of invested capital; } \\
\text { minimizing capital } \\
\text { investment payback } \\
\text { period }\end{array}$ \\
\hline
\end{tabular}

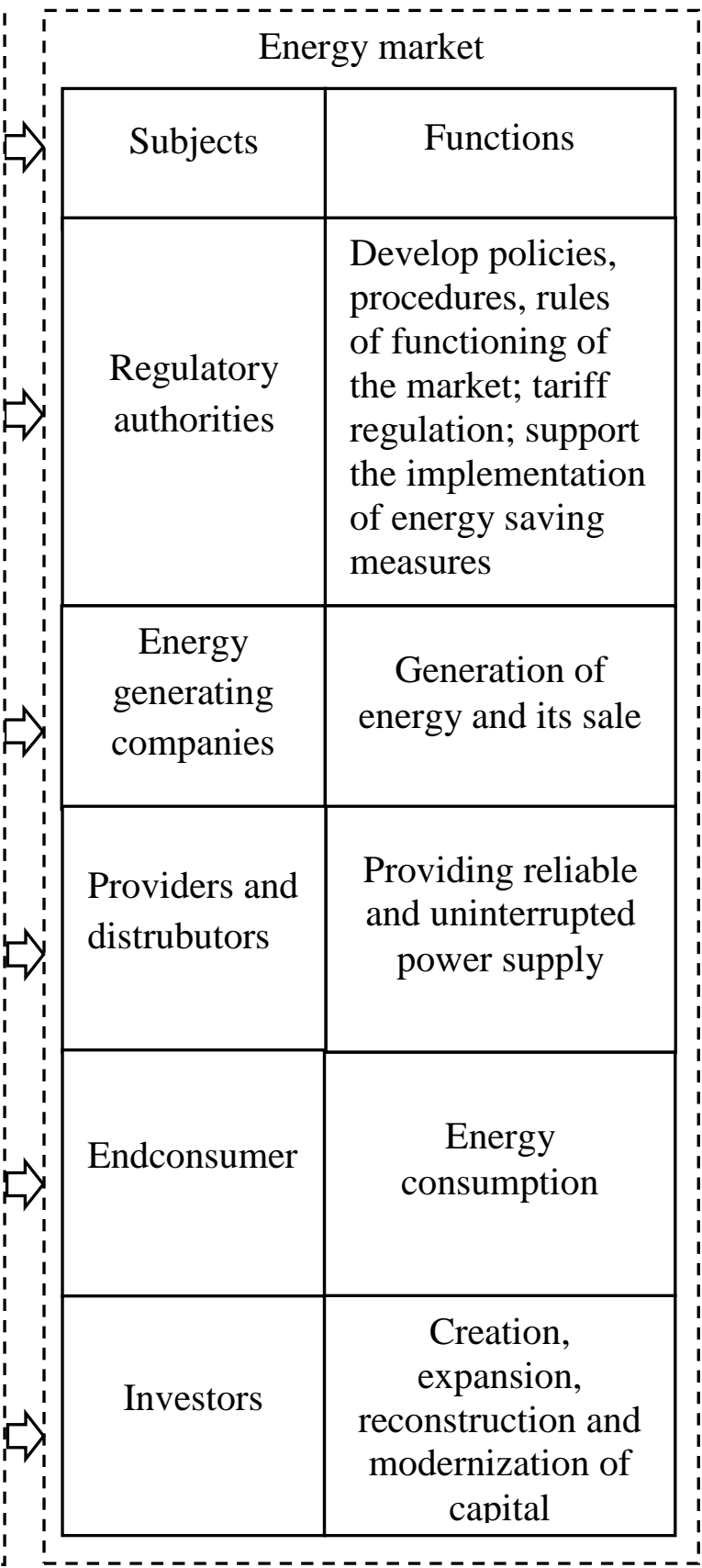

Figure 1. Subjective-functional structure of economic interests of the energy market

Source: authors' work

Therefore, the following main principles of vertical interplay can be identified:

- the principle of a common goal - the subjects acknowledge the priority of a common goal instead of pursuing individual goals and aim at achieving a common result; 
- the principle of openness - it encompasses open information and participation in common talks; base;

- the principle of voluntary acting - cooperation of the entities on a voluntary

- the principle of equality - the entities behave as equal partners, inter alia when having different points of departure, different financial means and other opportunities;

- the principle of reciprocity - participants realize their economic interest, in particular in the form of profit or savings of resources (i.e. financial);

- the principle of concreteness - clear definition of objectives, the results, the participants, their rights and duties;

- the principle of coordination - the presence of a coordinating body, which makes the entities act coherently;

- the principle of a common and open dispute resolution - in case of disputes between the parties, the problem discussion is discussed openly.

In Fig. 1 the ambiguity of the dialectic of economic interests of producers and consumers of electric energy associated with the imperfection of state regulation of can be traced. For instance, contradictory interests are inherent to all natural monopolies resulting. This, in turn results in the mechanism of monopoly pricing and the lack of stimulating factors to reduce costs and improve product quality under the conditions of state regulation of tariffs on a «cost plus $\mathrm{x}$ » base. The lack of a clear and transparent regulatory and procedural framework governing the procedure for determining the economic feasibility of expenses included in the electricity tariffs was the cause of the possibility of deliberate overstatement of costs companies in the sector.

Being on the opposite sides of economic relations, energy companies and consumers share common interests in the market. Without satisfying the consumers' interests, the producer cannot satisfy its own interests. The interdependence of these groups objectively determines their cooperation. Therefore, an important aspect of the organization of economic relations in the energy sector is the underlying public policy, providing for the balancing of economic interests of energy companies and energy consumers (Fig. 2).

In numerous countries, an effective energy policy is achieved by ways of either preserved state regulation (France, Norway, Sweden, Finland) or by ways of practice of public partnerships (maintaining regulatory and control functions) with power companies (Germany, Italy).

According to international experience three major energy regulation mechanisms such as regulation, co-regulation and competitive mechanisms can be seen. The scope of state regulation of the energy sector includes institutional, technological and environmental aspects of the energy companies, as well as social and labor relations and labor protection. In the field of economic relations that are 
subject to state regulation, the regulated issues relate to national security, control over the implementation of quality standards of service, charging decisions, compliance with access to electric power companies, supervisory control and management, and antitrust regulation.

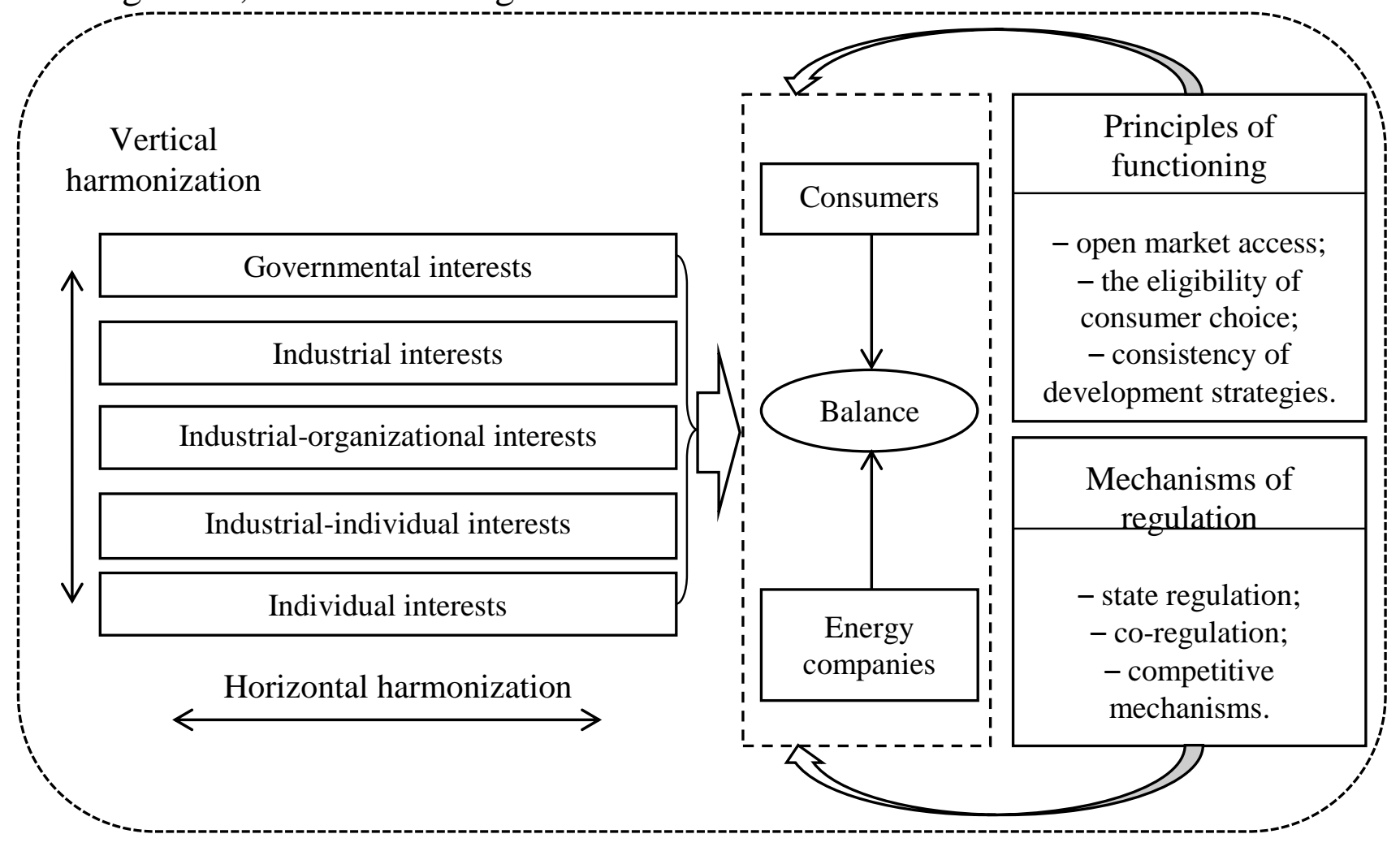

Figure 2. The functioning of the energy market based on the harmonization of the economic interests of its subjects

Source: authors' work

The scope of co-regulation covers those aspects of economic activities of energy companies, which are related to ensuring the balance of interests of participants of the energy market, regulation of prices and tariffs for electricity; planning and forecasting industry development, ensuring consistency of plans and programs of the sector at all levels (nano, micro, meso, macro).

Against this backdrop it is necessary to take a closer at Germany, who in 2009 switched to an incentive based regulation of the energy market.

Until 2009 Germany followed the approach of profitability, thereby relying on calculations provided by the Federal Net Agency (Bundesnetzagentur), which were based on factual income and loss numbers. With the introduction of incentive regulation, Germany increased the incentive for network operators to reduce their costs and thus increase efficiency. By applying an incentive regulation, regulatory authorities individually pre-determine the cost-effectiveness by using the upper income limit, which is the control period (five years), which changes only 
minimally. This upper limit of income is an incentive for network operators to make efforts to improve efficiency, so as to increase their profits.

The upper income limit is determined by analyzing the costs. In this case the network operator costs are calculated in the period which precedes the scheduled period of regulation. For the basic value of this time the regulatory authorities take the value for the last completed fiscal year. This year also called the base year. The costs in the base year are crucial for determining the upper limit of income for the next adjustment period. So are the costs incurred in the base year.

In the light of the above said, Cambini and Rondi [14] evaluated 23 major energy suppliers in France, Germany, Italy, Spain and UK and shown that incentive based regulation has major positive effects on the energy supplier's investments.

The same results were found by Cullmann, A., Dehnen, N., Nieswand, M., Pavel, F. [10]. Their research showed that incentive base regulation does not have a negative effect on the investment of operators. Indeed, it is the other way, i.e. the incentive based regulation approach provides for significant positive effects and stimulations for investments. Further, the research shows that this kind of effect is directly associated with the regulation approach, because a major rise is fond in the base year of inception of the method of regulation.

In turn, the scope of the implementation of competitive mechanisms should be applied to the rules of formation of organizational structure of the energy market, including the conditions of entry and exit in the wholesale and retail electricity and capacity markets.

By way of example, one should look at the 2008's EU «Climate and Energy Package 2020» [15] aiming at a decarburization of EU's economy. This package obliges EU Member States to decrease the emission of carbon by $20 \%$ until 2020 and to increase the usage of renewable energy to $20 \%$. To achieve these goals, the infrastructure needs major investments in highly decarbonized technologies. Additionally, the infrastructure shall provide a secure energy support and increase its efficiency.

According to an empirical study of DG Competition [16] a direct relationship between governmental intervention in the form of competition policies and direct positive effects on the market can be established. In such a case competition, private investments, low prices and the increase of production are directly connected to the governmental involvement.

Based on the above said it is possible to summarize governmental deregulation on energy markets as follows in Figure 3. When in 2011 Ukraine obtained the status of a Contracting Parties in the European Energy Association (EEA), Ukraine obliged itself to fulfill several demands, which inter alia encompass the establishment of a common EEA legal fields on the energy markets of the Member States of the EEA, particularly implementing Directive 2009/72/EC [20], that foresees the obligation to deregulate the energy market. 


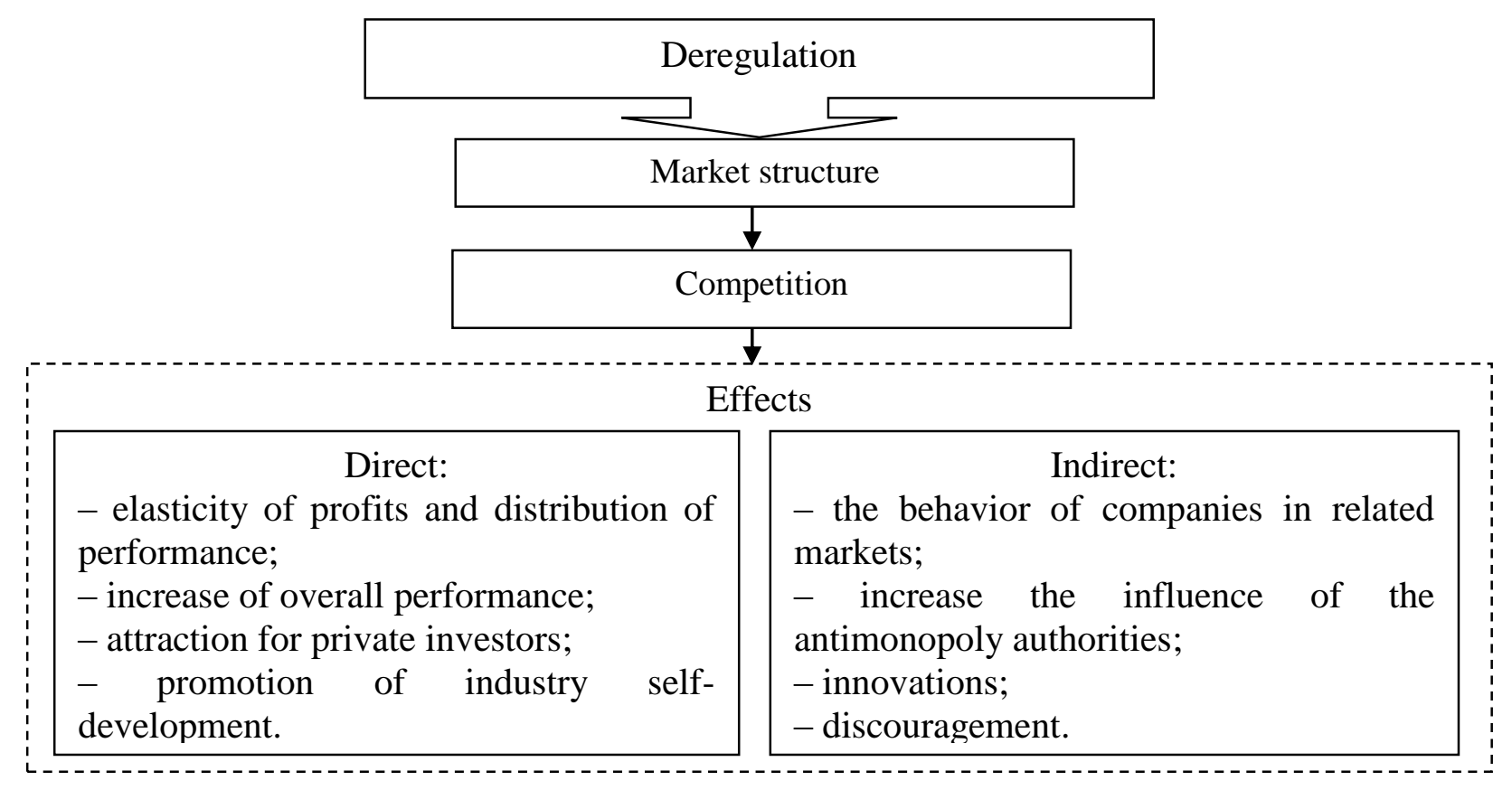

Figure 3. Effects of deregulation on the energy market Source: authors'work

Taking into account that the energy branch is influenced by governmental regulations, the process of formation of the competitive environment, above all, will be accompanied by institutional changes, that is, the organizational and structural adjustment of the market. Changing the model of market organization, in turn, will make it possible for new entities to enter the energy market, particularly in the mining sector (electricity generation) and the supply of natural gas and electricity.

The increased level of competition will lead to the distribution of production amongst the market players and a change in the investment strategies of energy corporations. Simultaneously, changes in the market will lead to an increase of private investments and indirectly to a production increase. Additionally, competition in the long run provides for positive results such as individual production increases, being the main force behind economic growth.

However, competitive policy also involves indirect effects, such as the change of behavior of companies acting on neighboring markets, the increase of the influence of governmental antimonopoly organizations which in turn force the companies to follow the rules as well as to innovations caused by increased investments. Such effects, according to Duso T. [7] and Joskov P. [8], also stimulate investments in other branches of the energy market, such as production and distribution and indirectly influence companies on neighboring energy markets.

Several scholars [9; 10] analyzed the effects of deregulation in public transport, telecommunication, electricity and gas. The research showed that reforms that encouraging market competition have a significant positive effect on 
investments in these fields. Such results can be particularly found in liberal markets following the incentive approach such as Germany.

According to the European strategy for sustainable, competitive and secure energy [17] in order to achieve a competitive internal energy market an effective legislative and regulatory framework must be developed, adopted and used in practice. Among these measures, in addition to a sufficient legal basis, it is necessary to provide: an adequate power level to ensure a balance between supply and demand for electricity; a sufficient level of investment in infrastructure, which provides energy transportation, etc.

Thus in order to solve the problem of conflicts of interest, the authors offer to apply the principles of coordination of economic interests of participants of the energy market, namely the unification, institutionalization, disintermediation and liberalization (Figure 4.).

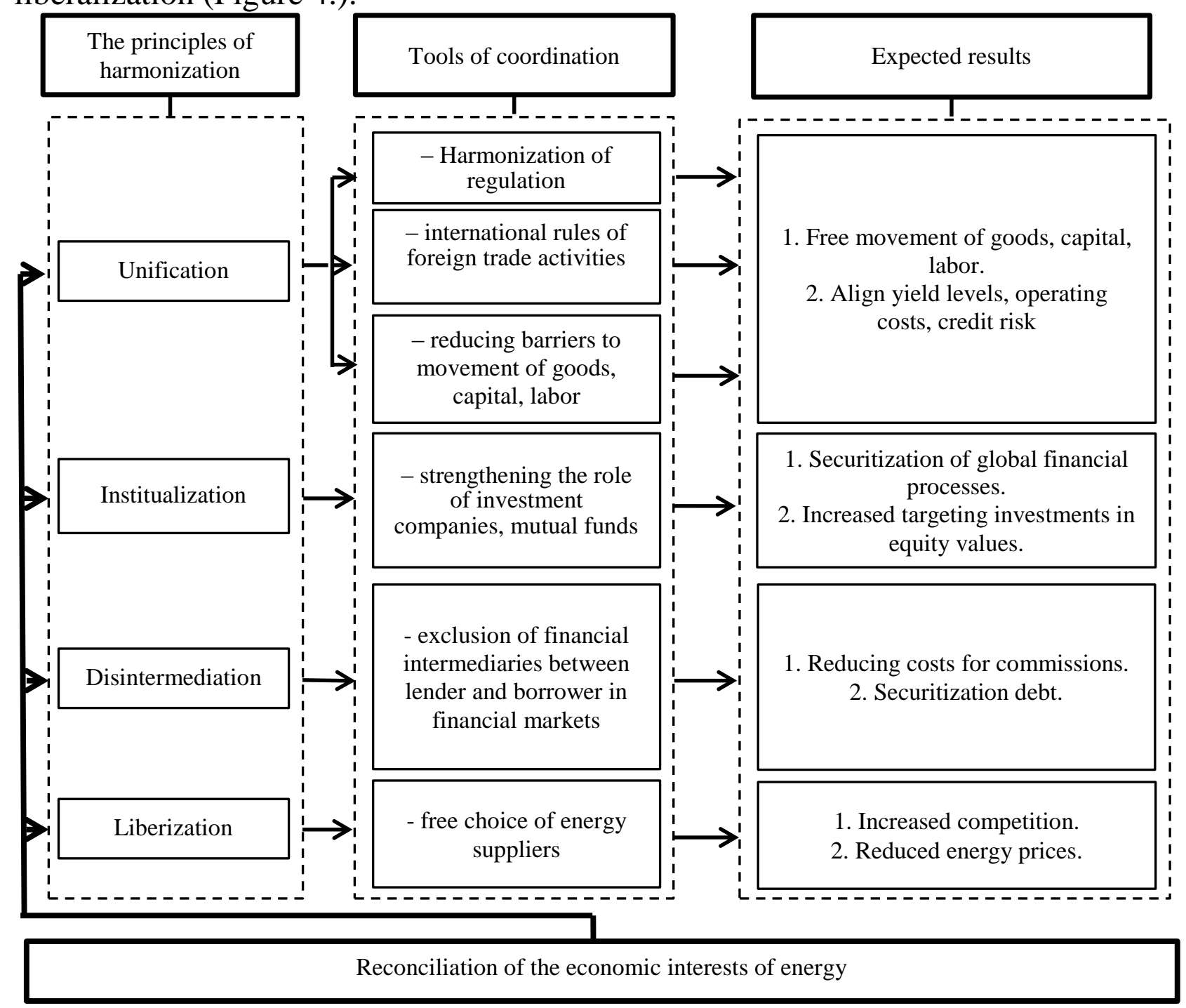

Figure 4. Reconciliation of the economic interests of the energy market Source: authors' work on the basis of [18; 19] 
The proposed principles and their tools of coordination will lead to a change in the relationships in the energy sector. For example, by eliminating the speculative intermediary links in the "producer-consumer» chain, which significantly increase the price of goods, the share of the producers in their price will increase.

The proposals mentioned above have the goal of harmonizing economic interests (which are often opposite) of economic entities in order to achieve the main goal - to create a single competitive energy market.

Results. The change in the direction and content of economic interests, is due to the emergence of new facilities and activities. This change contributes to the emergence of contradictions. Implementation of different economic interests of different players in the energy market is only possible by systematic organization of economic relations, which, in turn, can be carried out through the implementation of the principles of coordination, providing for a compromise of interests.

The scientific novelty of this study is the improvement of the subjective and functional structure of economic interests in the energy market, which, unlike the existing ones, provides for a relationship between the activities of the economic entities acting on the energy market and their economic interests which are reflected in their vertical and horizontal interaction. The authors further concretize the concept of «economic interests» that, in contrast to previous studies, is defined as a form of satisfaction of existing and developing needs based upon the principle of economic profit by means of material necessities of individuals, corporate entities and governments. The authors further developed a grouping of the effect of the deregulation of the energy market, which, unlike the existing ones, provides for distribution in accordance with the direct and indirect effects of competition policy functioning in the energy market; the principles of harmonization of economic interests of participants of the energy market, which, unlike the existing ones, can solve problem of conflicts of interest in the areas of production, transmission, distribution and consumption by ways of coordination tools and can create a competitive single energy market.

The authors see potential need in research in the development of scientific and methodological approaches to identify the factors and threats of economic security of the energy market in the process of transformation.

The practical significance of the results that form the substance of the study is laid out in the authors' guidelines to harmonize the economic interests of entities of the energy market that can be used by public authorities in the development of economic security when developing Ukraine's energy market strategy.

\section{Literature:}

1. Varnalii, Z. S., Melnyk, P. V., Tarangul, L. L. (2009). Ekonomichna bezpeka [Economic security]. K. : Znannia, 647 p. 
2. Kozachenko, G. V., Ponomarov, V. P., Liashenko, O.M. (2003). Ekonomichna bezpeka pidpryiemstva: sutnist ta mekhanizm zabezpechennia: monografiia [The economic security of the enterprise: the nature and mechanism of ensuring: monograph]. K.: «Libra», 280 p.

3. Muntiian, V. I. (1999). Ekonomichna bezpeka Ukrainy: monografiia [The economic security of Ukraine: monograph]. K.: KVITS, 464 p.

4. Alsuf'ieva, O. O. (2015). Mekhanizm uzghodzhennia ekonomichnykh interesiv sub'iektiv natsionalnoi ekonomiky: rivni ta zasoby koordynatsii [The mechanism of coordination of economic interests of the national economy: the level and means of coordination]. Dnipro: Economic Bulletin of National Mining University, 1, pp. 34-43.

5. Bezbozhnyi, V. L. (2008). Alhorytm vyboru sposobu harmonizatsii interesiv sotsialnoekonomichnoi bezpeky pidpryiemstva [The algorithm of method's selection of harmonizing the interests of socio-economic security]. Luhansk: Collected Works of Volodymyr Dahl East Ukrainian National Universuty, 20, pp. 199-206.

6. Riabtseva, N. V., Alsuf'ieva, O. O (2013). Mekhanizm uzghodzhennia ekonomichnykh interesiv $\mathrm{V}$ innovatsiinii makroekonomichnii systemi [The mechanism of coordination of economic interest in the innovation macroeconomic system]. Dnipro:Economic Bulletin of National Mining University, 2, pp. 77-84.

7. Duso, Tomaso; Seldeslachts, Jo; Szücs, Florian (2016). EU Wettbewerbs politik fördert Investitioneninden Energiesektoren, DIW-Wochenbericht, Vol. 83, Iss. 15, pp. 282-290.

8. Joskow, P. L. (2012). Transaction cost economics, antitrustrules, andremedies. Journal of Law, Economics, and Organization 18, 1, pp. 95-116.

9. Alesina, A., Ardagna, S., Nicoletti, G., Schiantarelli, F. (2005). Regulation and Investment. Journal of the European Economic Association, 3, 4, pp. 791-825.

10. Cullmann, A., Dehnen, N., Nieswand, M., Pavel, F. (2015). Keine Investitionshemmnisse in Elektrizitäts- und Gasverteilnetzen durch Anreizregulierung. DIWWochenberichtNr.6/2015, pp. 98-104.

11. Schumacher, E.F. (2000). Small Is Beautiful: Economics As If People Mattered. 25 Years Later... With Commentaries / E.F. Schumacher [introduction by P.Hawken]. Vancouver: Hartley and Marks Publishers, 286 p.

12. Pro osnovy natsionalnoi bezpeky Ukrainy [On the basis of national security of Ukraine] [Electronic resource] // Verkhovna Rada of Ukraine [Official website]. - Access mode: http://zakon3.rada.gov.ua/laws/show/964-15

13. Glina, V.N. (2006). Ekonomycheskaia sotsyolohyia [Economic sociology]. Grodno : GrGU, 96 p.

14. Cambini, C., Rondi, L. (2010). Incentive regulation and investment: evidence from European energy utilities. Journal of Regulatory Economics 38, pp. 1-26.

15. 2020 climate \& energy package [Electronic resource] // European Commission [Official website]. - Access mode: http://ec.europa.eu/clima/policies/strategies/2020_en

16. The Economic Impact of Enforcement of Competition Policies on the Functioning of EU Energy Markets: non-technical Summary and Technical report [Electronic resource] // European Commission [Official website]. - Access mode: http://ec.europa.eu/competition/publications/reports/kd0216007enn.pdf

17. Green Paper. A European Strategy for Sustainable, Competitive and Secure Energy 2006 [Electronic resource] // Commission of the European communities [Official website]. Access mode: http://fire.pppl.gov/eu_energy_greenpaper_030806.pdf 
18. Willie, J.H. (1997). European security in the new political environ: Analysis of the relationship between nat. interests, intern, institutions a the great powers in the post-Coldwar Europ. Security arrangements. L; N.Y.: Longman, $140 \mathrm{p}$.

19. Hershkovych, B. Ia. (1999). Ekonomycheskye interesy i ikh realyzatsyia: materialy spec. kursa. [Economic interests and their implementation: specialized course materials]. Piatyhorsk: PGLU, $181 \mathrm{p}$.

20. Directive 2009/72/EC of the European Parliament and of the Council of 13 July 2009 concerning common rules for internal market in electricity and repealing Directive 2003/54/EC [Electronic resource] // EUR-Lex - Access to European Union law [Official website]. - Access mode: http://eur-lex.europa.eu/legal-content/EN/TXT/PDF/?uri=CELEX:32009L0072\&from=EN 